\title{
PGGT1B wt Allele
}

National Cancer Institute

\section{Source}

National Cancer Institute. PGGT1B wt Allele. NCI Thesaurus. Code C52049.

Human PGGT 1B wild-type allele is located in the vicinity of $5 q 22.3$ and is approximately $51 \mathrm{~kb}$ in length. This allele, which encodes geranylgeranyl transferase type-1 beta subunit protein, plays a role in plays a role in the post-translational modification of certain proteins via the addition of a geranylgeranyl group. 